\title{
SLIP OF THE TONGUE AND GENDER RELATION IN ADVANCE DEBATE COMMUNITY
}

\author{
${ }^{1}$ Mochammad Yusril Ihza Maldini , ${ }^{1}$ Rohmani Nur Indah \\ ${ }^{1}$ English Alumni, Faculty of Humanities, Universitas Islam Negeri Maulana Malik Ibrahim \\ Malang, Indonesia \\ Corresponding Author Email: indah@bsi.uin-malang.ac.id
}

\begin{tabular}{ll}
\hline \hline Article Info & Abstract \\
\hline Article History & This study discusses the slip of the tongue found in male and female debaters of \\
Received: August 2020 & Advance Debate Community (ADC). This particular topic is chosen with the \\
Revised: September 2020 & assumption that gender difference can influence slip of the tongue. It aims at \\
Published: October 2020 & describing how the slip of the tongue produced by male and female debaters on \\
\hline Keywords & ADC debate performance. In addition, it deciphers the factors causing the slips \\
Slip of the tongue; & of tongue. To get the intended results, this study used descriptive analysis to \\
Gender differences; & explain the existing data. The ADC debate record was converted to text \\
Speech errors; & manually. Then, the result was identified into the utterances containing slip of \\
& tongue. The researchers classified data types based on the slip of tongue model \\
& according to Caroll (1986). There are eight types of slip of tongue presented, \\
& namely: anticipation, perseveration, reversallexchange, blend, misderivation, \\
& substitution, addition and deletion. The findings show that the male debaters \\
produce more slip of tongue by displaying thirteen slip of tongue with five \\
different types, namely: anticipation, misderivation, substitution, addition, and \\
deletion. While female debaters display fewer slip of tongue, that is nine slip of \\
tongue but more varied with six different types, namely: anticipation, blend, \\
misderivation, substitution, addition and deletion.
\end{tabular}

How to cite: Maldini, M. Y. I \& Indah, R. N. (2020). Slip of The Tongue and Gender Relation in Advance Debate Community. JOLLT Journal of Languages and Language Teaching, 8(4), 360-369, DOI: https://doi.org/10.33394/jollt.v8i4.2828

\section{INTRODUCTION}

In debate competitions, debaters are always forced to speak fluently in giving their arguments. The accuracy of the speakers is needed because they have to provide arguments in large numbers and are easy to understand. In addition, using foreign languages in debates will be more challenging because they have to deal with words or sentences that they may not know. As Field stated, individual performance is determined by the strengths and limitations of the mental apparatus (Field, 2004). In this case, the debaters may produce tongue slips, especially when they have to rattle. But sometimes there are differences in the way the male debater and the female debater produce slips of the tongue because basically men and women do have different language skills. Therefore, this study aims to examine the differences in tongue slip produced by men and women during debates and the factors causing the slips.

The impact caused by the slip of the tongue in debate is very complex and varied. Asyura (2017) explains that in trivial cases language slips can be a language comedy because in everyday life slips of the tongue can indeed make the listener laugh. However, in larger and more sensitive cases, many errors in speaking languages such as language slips can create diplomatic problems between countries (Kawano \& Matsuo, 2002).

A slip of the tongue can happen to anyone and at any time. The slip of the tongue is partly due to production errors and the intentions of the speaker who slips on the tongue when speaking the sentence (Dardjowidjojo, 2008; Mayasari 2015). Actually in everyday life, every 
language speaker can produce a slip of the tongue without them knowing it. Besides, slip of the tongue can occur at any time and or any situation both formal and informal situations. Errors in speech, such as tongue slips are randomly produced and cannot be predicted. However, in many languages, including Korean, German, Spanish and Mandarin the slips show universal pattern (Han et al., 2019). In another sense, slip of the tongue is a mistake in planning discourse production; i.e. the speaker wants to say a lot of words, phrases, or sentences and suddenly something goes wrong, so the production is not according to the plan (Crus-Ferreira, 2007)

In another case, Fromkin et al. (2006) and Zheng (2006) have slightly different opinions in translating tongue slips. Fromkin et al. (2006) say that the slip of the tongue is closely related to the speaker's mind. For example, a nervous speaker will produce a slip of the tongue more often than a quiet speaker. Whereas in other cases, Zheng (2006) also said that the more professional a person spoke a second language, the less slip his tongue produced.

A slip of the tongue often appears in the use of a second language, which means that a person's ability to master a second language can be measured by how often he uses that language. That is what makes the tongue slip as an indicator of a person's ability to use language (Zheng, 2006, Indah, 2008). Whereas Altıparmak and Kuruoğlu (2014) states that slip of the tongue occurs because indeed the accident element is very high. In a recent study conducted by Fitriana (2018) revealed that slip of the tongue can occur even to someone who has been very reliable in speaking languages. In her study, Indonesian state officials who were proficient in English still could not convey the message of his speech smoothly. Apart from that, there are still many factors that influence people who produce tongue slips that are not clearly identified, one of which is gender differences.

Gender differences can affect language production either in the form of written expression (Wiyanto and Asmorobangun, 2020) or in speaking. It may also affect tongue slip production by speakers because in everyday life differences in speech between men and women are often encountered. Moreover, according to Cots et al. (1992) men and women do have fundamental differences in how they use language to communicate. This means that the narrative abilities of men and women are indeed different in various factors. As a clear example, women have more intelligence than men verbally that have even existed since birth according to (Cots et al., 1992).

The slip of the tongue in relation to gender differences is appear in the debate community at Malang State University. Therefore, the object of this research is a debate community at UIN Malang called Advance Debate Community (ADC). This object was chosen because the debate community has a higher level of English spoken proficiency in terms of debating skill than other English students. Also, the environment of UIN Malang forces them to be able to use languages other than English, which usually consists of Indonesian, Arabic and their respective regional languages. These facts reveal that ADC members have more than two languages that are mastered. As expressed in Zheng (2006) language proficiency is influenced by the frequent use of language using that language. ADC also consists of various students consisting of men and women.

This study starts from the situation that in the debate community at Malang State University called Advance Debate Community (ADC) many slip of the tongue appeared, then the number of slips of tongue that appear is assumed to be influenced by gender differences. In this study, Carrol's theory (1986) will help to understand how the slip of the tongue that appears in the debate community in Malang UIN and its relationship with the gender of the members.

The purpose of this study is to identify the types of slips of tongue appeared in the utterances of male and female debaters of Advance Debate Community (ADC) . In addition, it aims at describing the contexts supporting the occurence of the slips of tongue. As the 
significance, theoretically, the finding is expected to add insight in understanding the theory of the slip of the tongue and its relationship to gender. Practically, this research is expected to be able to make language learners improve their language skills, and minimize the production of tongue slips to reduce misunderstanding in speech.

\section{RESEARCH METHOD \\ Research Design}

This study used descriptive qualitative research methods because the researcher revealed events or facts, circumstances, phenomena, variables, and circumstances that occur when the research took place by presenting what actually happened. This study interpreted and illustrated data relating to the situation that was happening. In this case, the phenomenon occurred is in the arguments and utterances spoken by ADC members so that it can cause several slips of the tongue produced by men and women.

\section{Subject}

The data source in this study is in the form of video and audio recordings obtained by recording the ADC debate performance. The video and audio contain two periods of debate performance with a total duration of forty-five minutes. Records and other documentation are focused on male and female debates. The debate consisted of eight members with four men and four women. The recorded data were taken during the ADC training period facing the race on the 22nd and 29th of February 2020.

\section{Instruments}

This study used non-participant observation as the main instrument to get data in the debate hall because the researcher focused on the slip of the tongue experienced by ADC debates when conducting debates. In this case, several tools were used to assist the process of collecting data such as video and audio recording, documentation, field note and also recording. Video and audio recordings were used to assist in finding data. As for documentation, it was used as evidence that the research had conducted observations. Then, the recording was used to support findings that might not be recorded.

\section{Data Analysis}

In analyzing the data, several steps were included in this study. First was identifying the types of slip of tongue produced by female and male debaters based on Carrol (1986). Then, the next step was classifying the slips of the tongue based on gender. making it a percentage of the slip of the tongue difference produced in both. Finally, the final stage was drawing conclusion on the differences in slip of tongue produced by male and female debaters.

\section{RESEARCH FINDINGS AND DISCUSSION Types of Slips of The Tongue of Male and Female Debaters}

The data cover eight debating subjects converted into transcripts. Among these subjects, there were four male debaters and four female debaters who argued either positive or negative teams in the debate. The video wereconverted into a transcript to help the researchers identify the data. First, the researchers filtered hundreds of collected data into forty-six. The data reduction was made to find data that only has special characteristics according to the classification. After that, the researchers refined the data again intending to avoid saturated data. The data that had the same pattern were categorized as a datum. In the most recent screening, the researcher found a total of sixteen datum consisting of nine datum ofmale subjects and seven datum offemale subjects. Various data above were analyzed based on the theory of a slip of the tongue based on Carrol (1986). In the analysis, the datum was analyzed 
based on the context, type, and function. The summary of the analysis is as presented in Table 1.

Table 1.

Types of Slips of The Tongue

\begin{tabular}{|c|c|c|c|}
\hline No. & Gender & Utterances & Types \\
\hline 1 & Male & $\begin{array}{l}\text { The church is a holy place to practice gany kind of activity to } \\
\text { serve of the god }\end{array}$ & Substitution of adjective \\
\hline 2 & Male & $\begin{array}{l}\text { However, the crime has been happening in that place, for } \\
\text { example, sexual harassment. The subject of this problem is } \\
\text { about the the price the priest }\end{array}$ & Substitution of noun \\
\hline 3 & Male & $\begin{array}{l}\text { We come to the statement that the church forbidden the priest } \\
\text { to marry, that's why their desire to having sexual activity is } \\
\text { misspredictable }\end{array}$ & $\begin{array}{l}\text { Addition of verb } \\
\text { Misderivation of adjective }\end{array}$ \\
\hline 4 & Male & $\begin{array}{l}\text { By the seeing that, we can take a proof, every human have the } \\
\text { same right to the get married }\end{array}$ & Addition of article \\
\hline 5 & Male & $\begin{array}{l}\text { Church is a that we know that church is a holy place to practice } \\
\text { any kind of religious activity }\end{array}$ & $\begin{array}{l}\text { Addition of repetitive } \\
\text { phrase }\end{array}$ \\
\hline 6 & Male & $\begin{array}{l}\text { It means that we need that priest maintain to be able serve the } \\
\text { kind of model good model }\end{array}$ & $\begin{array}{l}\text { Deletion of infinitive } \\
\text { Addition of noun }\end{array}$ \\
\hline 7 & Male & $\begin{array}{l}\text { However, there are social harassment that happen toward the } \\
\text { priest itself such as pedhophilia }\end{array}$ & Substitution of adjective \\
\hline 8 & Male & $\begin{array}{l}\text { We know it legis and gentleman, as human beings we have to } \\
\text { avoid pedohilia }\end{array}$ & Anticipation of noun \\
\hline 9 & Male & $\begin{array}{l}\text { Pedophilia is a sexual harassment toward kid under eight } \\
\text { twenty age }\end{array}$ & $\begin{array}{l}\text { Substitution of noun } \\
\text { Addition of noun }\end{array}$ \\
\hline 10 & Female & But then this bioloneeds doesn't have their way out & Blend of noun \\
\hline 11 & Female & Many sexual crimes were committed by prince, price, priest & Substitution of noun \\
\hline 12 & Female & The crash church forbade priest to marry to mary & $\begin{array}{l}\text { Substitution of noun } \\
\text { Repetition of verb }\end{array}$ \\
\hline 13 & Female & $\begin{array}{l}\text { This case have been happening and uncrease in every year, } \\
\text { with this idea we want to remake the celabacy crule }\end{array}$ & Misderivation of verb \\
\hline 14 & Female & $\begin{array}{l}\text { It's because the bhruch forbade the priest to get married even } \\
\text { though they desire to get married is unavoidable }\end{array}$ & Anticipation of noun \\
\hline 15 & Female & $\begin{array}{l}\text { Do ladies and gentlemen know the amount of sexual abuse } \\
\text { each year? They key and they keep increasing ladies and } \\
\text { gentlement }\end{array}$ & Preservation of verb \\
\hline 16 & Female & $\begin{array}{l}\text { Our groal is very clear ladies and gentleman, it is to make the } \\
\text { church a safe place for worship }\end{array}$ & f noun \\
\hline
\end{tabular}

Cots et al. (1992) state that men and women have fundamental differences in how they communicate. Even men and women already have differences in verbal intelligence from birth. This intelligence ability can also affect men and women in producing speech errors, one of which is tongue slip. Therefore, a slip of the tongue produced by men and women can be different in everyday life.

According to Clark and Clark (1977), mistakes in speaking can often be encountered when the speaker makes a spontaneous speech without preparation. The debate is one example of that speech. Therefore the debate has the potential to produce many speech errors, especially a slip of the tongue. In this case, the classification of tongue slips commonly occurs is concluded in eight types based on Caroll (1986). These types include anticipation, perseveration, reversals, blends, misderivation, substitutions, additions, and deletions. 


\section{Substitution}

Substitution occurs when the speaker replaces words with totally different meanings than they should, thus make the listener confused (Caroll, 1986). The meaning that the occurrence of substitution can be influenced by many things both internally and externally, consequently the word that appears as a substitution sometimes has a meaning that is very far from the actual word. Therefore substitution can make the listener very confused when faced with it. The emergence of substitutions does not have a clear pattern, and sometimes the word being replaced has the meaning of the word that it should be so that many listeners sometimes experience misunderstandings with the speaker. This type of tongue slip occurs quite a lot in the data above.

For example subtitutions appears in datum 1 "The church is a holy place to practice gany kind of activity to serve of the god". In the sentence above the word "gany" has no meaning. The word should be "any" but several factors make the speaker change the word to "gany". Another example is in datum 12 "The crash church forbade priest to marry to mary". The speaker says the word "crash" when the truth is the word "church". Besides, in this sentence, the speaker also repeats the correct word, the word "to marry".

Substitution is the type of a slip of the tongue that most often found in data. Counted, there are 7 substitutions produced, namely in datum 1,2, 5, 6, 7, 11, and 12. In this type of a slip of the tongue, men produce at most 5 times, while female speakers are only 2 times. In this case, subtitutions appear in the data after verbs, prepositions, adjectives and articles. These subtitutions occur randomly. There is no specific pattern in the sentence structure that determines the appearance of this type of slip of the tongue because no dominant type of word appears before the subtitutions appear.

\section{Additions}

The addition is a slip of the tongue that appears when the speaker adds linguistic elements to a word (Caroll, 1986). The addition is additional linguistic material. It is usually related to phonemes, morphemic affixes (prefix and suffix), articles, prepositions, conjunction, whole phrases, or even phrases. Speakers recognize a bargain approximately how they choose the words they're going to say. Additions have the potential to be a type of a slip of the tongue that appears a lot. Still, we don't realize as a listener, because additions sometimes only add a small element of a sentence that often makes the sentence look like a proper sentence.

In the data above Addition is in datum 4 "By the seeing that, we can take a proof, every human has the same right to get married". The addition of the "the" article in the sentence above is grammatically incorrect, the article has no meaning and should not appear in that sentence. Another example is in datum 15 "Do ladies and gentlemen know the amount of sexual abuse each year? They key and they keep increasing ladies and gentlement". In this case the speaker adding a new segment which is a conjunction word. The conjunction "and" should not be there, because the writer should only say "they keep" without adding any words.

The additions also appear in datum 3, 4, 5, 9, and 15. These types of slips of the tongue do appear quite often in the data above. Most of the Additions are spoken by male speakers, while female speakers only produce one time. The additions are the type of slip of the tongue that appears most in the data after additions. In this case, additions often appear after the words noun, preposition, verb and conjunction.

\section{Anticipation}

The anticipation occurs when the speaker anticipates a segment because it is affected by the word afterward. Still, anticipation is different from Misderivation because the anticipated 
segment is not used repeatedly (Caroll, 1986). On the other hand, several items are planned in the utterance as anticipation and affect the units previously planned in the utterance.

This type of slip of the tongue occurred in datum 8 "We know it is legis and gentleman, as human beings we have to avoid pedohilia". In the word "legis", the speaker anticipates the segment on "gentleman" which should be in the form of the word "ladies". Another example is in datum 16 "Our groul is very clear ladies and gentleman, it is to make the church a safe place for worship". In this uttarance, the speaker anticipates the "gr" segment in the "goul" of the word "very, so the speaker speaks the word" groul "which sounds funny to the listener's ear.

\section{Deletion}

The deletion is arguably the opposite of addition. This type of slip of the tongue occurs when the speaker erases the linguistic elements in a word. Deletion is leaving something out. The speaker desired to utter the intended sentences, yet incidentally, he/she left out a linguistic cloth. It may be usually associated with phonemes, morphemic affixes (prefix and suffix), articles, prepositions, conjunctions, whole phrases, or even in saying his / her supposed utterance. Deletions have the potential to be a type of tongue slip that appears a lot. Still, we don't realize as a listener, because deletions sometimes only remove a few elements from a sentence that often makes the sentence look like a proper sentence.

The deletion is found in datum 11 "Many sexual crimes were committed by prince, price, priest". In datum 11, there should be an article before the word "priest". The article can be either "a" or "the" so that the data's sentence structure can be grammatically correct. Another example is in datum 6 "it means that we need that priest maintain to be able serve the kind of model good model". in this sentence the speaker removes the word "to" in "to serve" so that only the word "serve" appears which confuses the listener at that time.

\section{Misderivation}

Misderivation or shift is a type of a slip of the tongue that occurs when the speaker uses affixation that is not following either the prefix or suffix (Clark and Clark, 1977). Misderivations are one speech section disappears from their appropriate actions and appears somewhere else. The part that disappears from misderivation will sound funny when heard because the two elements seem to fuse to make it easier for the speaker to speak with a fast tempo.

Misderivation appears in datum 3 "we came to the statement that the church forbidden the priest to marry, that is why their desire to have sexual activity is mispredictable". In the word "mispredictable" in the sentence above, the speaker uses the prefix "mis". The prefix is not appropriate for the word, the word prefix should be "un" so that it becomes "unpredictable".

\section{Blends}

Blends are a type of a slip of the tongue that occurs when the speaker combines two or more words into one (Caroll, 1986). Most blends happened when the speaker tried to say both words quickly together. The two or more words do not have clear levels in their division. Blends can divide half of the first word and half of the second word or even just a quarter of the first word and the rest of the second word. Blends can also sometimes be said deliberately because various examples have become slang words in English.

The blend occurs in datum 10 "But then this bioloneeds doesn't have their way out". In that sentence the speaker combines the two words "biological" and "needs" into the word "bioloneeds". The speaker has difficulty saying the word "biological" so she tries to pronounce the word quickly while combining it with the word "needs". 
The blend only appears once in the data, and only female debater produce Blends. Blend appear so little that it is difficult for the researcher to find the appearance patterns of this type. In this data, blend appears after pronouns.

Based on the explanation finding above, the following is the comparison of the slips of the tongue based on gender which is presented in the form of a diagram. Figure 1 explains the number of tongue slips produced by male debaters, while Figure 2 describes the number of tongue slips provided by female debaters. Both images were obtained based on Caroll (1986). The difference supports the finding of Bortfield et al. (2001) that gender becomes a significant factor affecting disfluency rate. It also in line with the finding of Marx (1999) that the language processing of both gender is related to specific properties of speech errors in the context of German language. This fact not only occurs in the context of English as foreign language in Indonesia, but also in Chinese language. Gender becomes a possible reason in the occurance of slips of tongue, where female speakers tend to produce higher pitch as feminine characteristics (Erway, 2004).
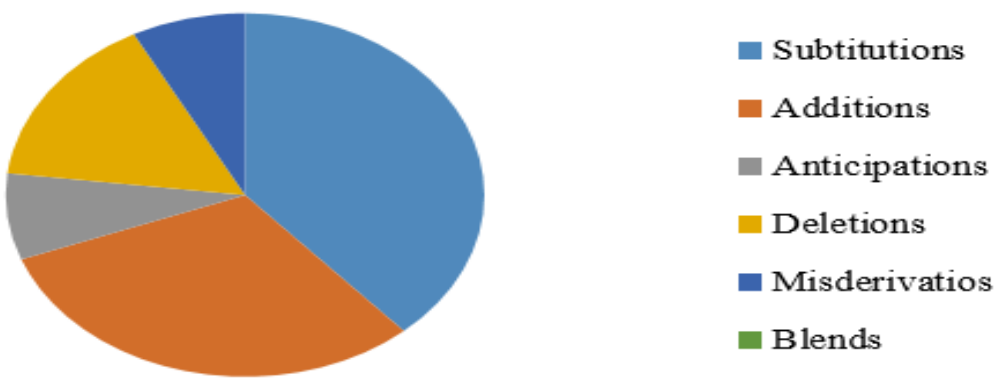

Figure 1. Slip of the tongue by male debaters.

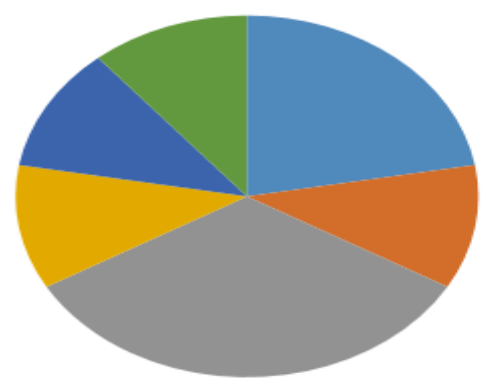

$$
\begin{aligned}
& \text { - Subtitutions } \\
& \text { " Additions } \\
& \text { " Anticipations } \\
& \text { = Deletions } \\
& \text { - Misderivatios } \\
& \text { - Blends } \\
& \text { - Reversals } \\
& \text { - Perseverations }
\end{aligned}
$$

Figure 2. Slip of the tongue by female debaters.

\section{Factors Causing the Slips of Tongue of Male and Female Debaters}

From the observation conducted in two debate performances, the researcher also observed the causes that influenced a slip of the tongue produced by the male and female debaters. The analysis on factors causing the slips of the tongue is also supported by the data from the field note. It covered the description of the interaction during the debate, and the nonverbal communication used such as gesture, eye contact, facial expression, and the behavior of the debaters. The reasons that happened in both video are quite similar, although the debate performance has a different topic. Therefore, the researcher concludes that all causes are present in this discussion, but each debater has its own portion. In this case, Clark and Clark (1977) have discovered three possible sources of factors influencing people 
produce speech error especially slip of the tongue are cognitive reasons, anxiety, and social reasons.

Social reason is an external factor in the form of pressure that causes the debate to produce a slip of the tongue (Clark and Clark, 1977). in this case, Social reason occurs in debaters because debates force debaters to talk in a limited amount of time and lack preparation. After all, the topics in the debate are suddenly obtained. In the debate performance, each debater is required to speak within five to seven minutes with a topic that they are not too good at. Besides, the debaters who spoke did not have sufficient preparation to argue because the material was too sudden.

Next, the cause influencing students in both the first and second debates is the cognitive difficulty, in producing their speech it takes longer to produce sentences on the topic using abstract words rather than concrete words (Clark and Clark, 1977). At the word choice level, doubts arise when the speaker is having trouble finding the right words. This condition is also closely related to the cognitive ability of each different debater. In other cases, it is observed that debaters experience errors in constructing sentences, both lexically, syntactically, and grammatically. At the same time, they have material about the tenses that must be used in speaking.

Situational anxiety also occurs in debating performance because of certain situations that make the speaker tense, anxious, or worried about it. They tend to produce doubt in speaking. Anxiety breaks down planning and implementation, which becomes less efficient. Such anxieties in the form of worry will run out of time, then doubt about the truth of the argument in the debate and a very tense situation when the attention of many people when arguing. Also, the speakers have difficulty speaking cognitively when they are anxious. When people are worried about the topic to be conveyed, they tend to be more careful in choosing words that will be organized into sentences. They pay more attention to the dictionary they will talk about. It can be seen from their words that often cause a slip of the tongue to compose the right sentence.

The research findings are based on Caroll's theory (1986) and therefore, the results might be different under another theory, especially that of slip of tongue. Moreover, the researcher did not involve rhetorical patterns during debate observation. Thus, elements in the debate which specifically can influence debaters in producing slips of the tongue cannot be adequately listed. Furthermore, researchers cannot compare the object of the study with more debate cases due to the researcher's time and place limitation. Some of the points above are a limitation of this research, which is expected to be continued by other the researcher who are interested in this field.

This study agrees that male speakers and female speakers have differences in various linguistic spectrums. Some previous studies show that speech errors, especially slips of the tongue are assumed to be able to experience differences between male and female speakers. The difference between the two speakers of different genders is fairly broad in scope. Based on this research, the analysis above shows that female speakers and male speakers experience a difference in the amount of slip of tongue production in their debate arguments. In this case, male speakers do produce more slip of the tongue than female.

In another case, the study conducted by Fitriana (2018) revealed that female speakers were also shown to produce fewer slips of the tongue than male speakers. This study took a large sample of speakers from various ages, genders and backgrounds who have good English language skills. Fitriana assessed the entire slip of the tongue they produced by looking at the speech from the sample she had.

A study conducted by Altıparmak and Kuruoğlu (2014) examined native Turkish people with various backgrounds and age differences that were fairly varied without seeing gender as a problem. This research considers that there is a more important factor than gender 
differences in producing slips of the tongue. The factor is language education itself and also the age of the person. Older people tend to produce more tongue slips than younger ones, educated people can also minimize the production of slips of the tongue

Asyura (2017) found that a female speaker also made fewer speech errors than a man. This research examines the stand-up comedians at one TV station in Indonesia. In practice, One of the female comedians did produce the least speech errors, but Asyura (2017) considered that the comedian's readiness factor was more influential in how much they produced speech errors. The comedian who prepare the material well, are not nervous, and are less confident in producing speech errors.

Some of the research above shows that there is indeed a difference between male and female speakers in producing tongue slips. In some other study, the finding showed no significant difference between male and female in producing speech error and both gender tend to use repetition (Gascoigne, 2002). However, the different findings are in a broad spectrum, so some researchers are more likely to assume that more focused internal factors are the main reason female or men produce tongue slips. However, even more focused internal factors can be assumed to be influenced by different genders. Therefore, the authors conclude that gender differences do affect the number of people producing slip of the tongue.

\section{CONCLUSION}

The results of this study indicate that the types of tongue slips mentioned by Caroll (1986) appeared in the ADC debate. Male debaters and female debaters experience some differences in producing a slip of the tongue. This research shows that male debaters produce more slip of the tongue than female debaters in the whole data. Based on the data, male debaters produces substitution most often. There is no specific pattern in the texts in men. Often, male debaters provide additions. In this case, addition often appears after the verb. Occasional male debaters also produce anticipation. Moreover, male debaters rarely produce deletion. Male debaters also very rarely provide misderivation. In different cases, female debaters do produce fewer amounts of a slip of the tongue, but a slip of the tongue produced by female debaters are more varied. Female debaters produce anticipation most often. Anticipation always placed at the beginning of a sentence. Female debaters also sometimes produce subtitution. There is no dominance pattern in this kind of slip of the tongue. It is rare for female debaters to provide an addition. They just produced it once. Then, the female debater also provides a misderivation. Female debaters produce a blend. Only female debaters produced a blend. Two types of a slip of the tongue were not produced by either male debaters or female debaters, they are preservation and reversal.

There were indeed differences between male and female in producing tongue slip. However, this study does not explain in depth the rhetorical factors that occur in the debate mechanism, so that the elements that make a person produce a slip of the tongue besides the influence of gender can still happen. Therefore, future researchers are suggested to examine how the debate mechanism and rhetorical factors in it, to find gender differences in producing tongue slips with more directed and focused analysis. In addition, they should use different methods that can display daily conversations between men and women. By doing so, the data obtained will be more evident that a slip of the tongue is also influenced by gender. 


\section{REFERENCES}

Altıparmak, A., \& Kuruoğlu, G. (2014). Slips of the Tongue: A Psycholinguistic Study in Turkish Language. Humanities and Social Sciences Review, CD-ROM. ISSN, 21656258.

Asyura, M. (2017). Pause and Slip of the Tongue on Stand Up Comedy Show in Indonesia. IJASOS International E-Journal of Advances in Social Sciences, 3(7), 188-188. https://doi.org/10.18769/ijasos.309675

Bortfeld, H., Leon, S. D., Bloom, J. E., Schober, M. F., \& Brennan, S. E. (2001). Disfluency rates in conversation: Effects of age, relationship, topic, role, and gender. Language and speech, 44(2), 123-147. https://doi.org/10.1177\%2F00238309010440020101

Carroll, W. (1986). Psychology of Language. Pacific Grove

Clark, H. H., \& Clark, E. V. (1977). Psychology and language. Cambridge

Cots, J., Lleida, U. De. \& Tannen, D (1992). You just don't understand. Women and men in conversation. Sintagma: Revista de Lingüística, 4, 89-91.

Crus-Ferreira, M. (2007). Kids' slips: what young children's slips of the tongue reveal about language development. Journal of Child Language, 34(1), 189-194. https://doi.org/10.1017/s0305000906218002

Dardjowidjojo, S. (2008). Psikolinguistik: Pengantar pemahaman bahasa manusia. Yayasan Pustaka Obor Indonesia.

Erway, C. C. (2004). Gender Differences in Spoken Chinese, or, How To Talk Like a Real Chinese Man. Linguistics 101 Final Paper.

Field, J. (2004). Psycholinguistics: The Key Concept. Routledge.

Fitriana, M. (2018). Slips of the Tongue in Speech Production of Indonesia State Officials: A Psycholinguistic Study. International Journal of English Literature and Social Sciences, 3(4), 536-540. https://doi.org/10.22161/ijels.3.4.10

Fromkin, V., Rodman, R., Hyams, N., \& Hummel, K. (2006). An introduction to language: Third Canadian Edition. Nelson

Gascoigne, C. (2002). The role of gender in L2 interaction: Socialization via L2 materials. Encuentro Revista de investigación e innovación en la clase de idiomas, 13(14), 20022003.

Han, J. I., Oh, J., \& Kim, J. Y. (2019). Slips of the tongue in the Seoul Korean Corpus of spontaneous speech. Lingua, 220, 31-42. https://doi.org/10.1016/j.lingua.2019.01.001

Indah, R. N. (2008). Proses pemeroleh Bahasa: dari kemampuan hingga kekurang mampuan berbahasa. Lingua, 3 (1). ISSN 2442-3823. https://doi.org/10.18860/ling.v3i1.570

Kawano, N., \& Matsuo, M. (2002). Political Outcomes of the Slips of the Tongue of Japanese Ministers. Hiroshima Peace Science, 24, 197-221. https://doi.org/10.15027/15280

Marx, E. (1999). Gender processing in speech production: Evidence from German speech errors. Journal of Psycholinguistic Research, 28(6), 601-621. https://doi.org/10.1023/A:1023216927241

Mayasari, I. (2015). Senyapan dan Kilir Lidah dalam Produksi Ujaran (Kajian Psikolinguistik). Deiksis, 7(2), 123-132.

Wiyanto, M. S., \& Asmorobangun, P. W. (2020). Gender Differences of Students'writing Ability in Descriptive Text. JOLLT Journal of Languages and Language Teaching, 8(2), 153-161. https://doi.org/10.33394/jollt.v8i2.2314

Zheng, Q. (2006). Slips of the Tongue in Second Language Production. Sino-US English Teaching, 3(7), 71. https://doi.org/10.17265/1539-8072/2006.07.014 